\title{
Innovation of Local Governance in Educational Affairs in Kupang City Province East Nusa Tenggara
}

\author{
Carlos Manuel Maia Aloysius Liliweri Petrus Kase William Djani \\ Program of Doctor of Science Administration, Post-Graduate Program, University of Nusa Cendana
}

\begin{abstract}
The novelty of this research in: 1) public sector organization as research target; 2) research locus in the city of autonomous region which has the authority to regulate and administer the organization of education; 3) the innovation study in integrated regional government bureaucracy starting at the "executive" policy level, organizational managerial level, and innovation at the operational level. The objectives of the research are: a) process of development of program of the innovations of local government in education, b) kind of innovation program of local government in education, c) capacity of innovation of local government in education, and d) building the empirical model and recommended model of local government innovation in education. Researchers use the theory of innovation in the sector of the public which was developed by Mulgan \& Albury (2003) and Muluk (2008). In the study of innovation of public sector known there are five types, namely: a) the innovation of service product, b) innovation of service process, c) innovation of method of service, d) innovation of policy, and e) innovation of system. The results of the research are: 1) the process of the development of program of innovation in education through a process of politic (function of setting) and a process of the arrangement (the managerial) that had already been innovative; 2) the types of innovation program include Program Sanggar Pendidikan Anak/PSPA (Children Education Studio Program), Program Pendidikan Gratis/PPG (Free Education Program), Program Inovasi Metode Pembelajaran/PIMP (Learning Method Innovation Program), and Program Satuan Tugas Pendidikan/PSTP (Educational Task Force Program). The four programs of innovation are the kind of innovation of service process, incremental and top down, adopted through replication (clone) as a result of comparative study; 3 ) there are four elements of innovation capacity that are studied, namely, the innovative leadership of the mayor, implementing apparatus, budget, government network and program regulation.
\end{abstract}

Keywords: innovation, development, type, capacity, model, education

DOI: $10.7176 / \mathrm{JEP} / 11-5-02$

Publication date: February $29^{\text {th }} 2020$

\section{Introduction}

Administratively, Kupang City consists of 6 sub districts and 51 definitive kelurahans, which are a division of local government of Kupang District. Systemic studies need to be carried out after Kupang becomes the administrative area of the city, specifically regarding the affairs of education. Current empirical conditions occur paradoxically in local government in Indonesia. A region that was originally predicated as a district with the best public services, which was indicated by receiving an autonomy award, turned out to be in declining in the following year, not developing or stagnating. Only some have made progress in public service matters. There are two conditions as the cause, namely: a) a sense of the concept of innovation, and b) the internal environment of the organization, especially the leadership of the regional head. Therefore, the direction that should be done is not a "how to realize the innovation of local government (how to make the innovation of local government), "but rather "how to realize innovative local government (how to make the innovative local government".

The phenomenon of the world of education in the city of Kupang which is the main problem faced by local government so that it becomes important to conduct innovative programs covering 3 main problems, namely; 1) the still low accessibility of the community to educational service, 2) the high school costs felt by the community, and 3) the low quality of education, especially related to the quality of the learning process in schools.

The three main problems are weak accessibility, the high cost of education, and the quality of learning are still low impact on several things, namely: 1) the presence of illiteracy rates (ABA, Angka Buta Aksara) in the city of Kupang, namely, illiteracy rates $(A B A)$ in 2007 there were 12\%, in 2012 there were 8.09\%, and in 2017 there were $6.39 \%$. From 2007 to 2017 the illiteracy rate $(A B A)$ of Kupang City did show a declining number, but this area has always been a contributor to the high illiteracy rate $(A B A)$ in East Nusa Tenggara Province; 2) Education Index and Human Development Index (IPM, Indek Pembangunan Manusia) are still low despite an increasing trend. Kupang City Education Index in 2012 was only $69.79 \%$ and in 2017 becoming 71.78\%, while the Human Development Index (HDI) in 2007 was $67.42 \%$. In 2012 it increased to $70.67 \%$ and in 2017 that was $72.12 \%$.

In the context of previous research, the City of Kupang is an autonomous region that has carried out various policies and innovation programs in the administration of educational affairs. Now in Kupang there have been several new programs in the field of education carried out over the last ten years. Some of the policies and programs that are innovative in the service of education include: 1) developing the Children Education Studio 
Program (PSPA, Program Sanggar Pendidikan Anak) to Early Childhood Education (PAUD, Pendidikan Anak Usia Dini), 2) developing policy of free school fee that is packaged in the form of Free Education Program (PPG, Program Pendidikan Gratis), 3)developing the Learning Method Innovation Program (PIMP, Program Inovasi Metode Pembelajaran), and 4) establishing an Educational Task Force Program (PSTP, Program Satuan Tugas Pendidikan) at all levels of education (Elementary and Junior Levels).

This phenomenon is interesting to be investigated through the study of local government innovation in the administration of education into several research focuses, including: a) the process of developing of local government innovation program in organizing educational affairs which include political and managerial processes, b) the types of regional government innovation program in organizing the educational affairs, and c) the capacity of local government innovation in the administration of education. This research gave birth to an empirical model and a recommended model aimed at developing effective, efficient and professional local government innovation program.

Policy and innovation program of local government in the administration of educational affairs that have been carried out by Kupang City Government, actually began in pioneering since 1996. Because it was considered successful in the development and providing public service through these innovative policy and program, the following years the City of Kupang received the autonomy award from the Central Government to the City of Kupang because it is considered successful in the innovation program in the field of public service.

The policy and program innovations that have been implemented in Kupang City, show that this region has exercised its authority in regulating and managing public service matters. Even so, it does not mean that behind the success and appreciation it receives, the issue of public service no longer exists. But it must continue to be improved and maintained government innovation in the field of education in the city of Kupang.

Decentralization conceptually has many positive aspects, such as Smith (1985:18) believes that decentralization can bring benefits, among others: 1) economically considered to improve the efficiency, because the decentralization can reduce costs, increase output and human resources to be able to use more effective, 2) politically, decentralization can strengthen democracy and accountability, improve citizens' skills in politics and strengthen national integration. According to Suwandi (2007: 5), political objectives make positions of local government as a medium of political education for the community at the local level and in the aggregate will contribute to national political education for the realization of civil society. While administrative objectives will make positions the local government as a government unit at the local level whose function is to provide community services in the effective, efficient and economical manners. Fulfilling these two objectives is a must for local government in order to maintain accountability for the legitimacy given by citizen to local government to regulate and manage the community.

In the era of regional autonomy, according to Wahab (2002: 43) autonomous regions (province, district/city) have increasingly broad authority in the administration of government. An autonomous region must be brave and capable to be different (the capacity to create difference) from other regions. Regional autonomy provides space for "political maneuvering" for the region in expressing its autonomy policy. In the perspective of public administration, a very spacious room to be creative and innovative in managing local government called discretion (discretion).

Studies related to the innovation of educational affairs, which are conducted at local government level regions in Indonesia, not many do. Even if there is research on educational innovation, they are juxtaposed with innovation in other field. Therefore, the problems found in educational innovations are similar to the problems in implementing local government innovations in general. Research undertaken by Prasojo (2006) in Jembrana, research on innovation in the education and health sectors were juxtaposed so many obstacles and barriers of development in the same innovations.

At the state level there are several researchers that are related to management, learning processes and educational curricula at the school level. For example, research conducted by Ajibola (2008) in Nigeria that focuses on policy innovation in developing basic education curriculum. The problem found in this study is that curriculum capacity is no longer in accordance with the needs and demands of society as a result of dynamic environmental changes. In addition to this research, there is also research that focuses on innovation management in the education system in Nigeria. Research conducted by Akomolafe (2011) revealed that the problem faced by many schools in Nigeria today is the problem of the low creative culture of school students as a result of school management, leadership and an unsupportive school environment. Therefore, policy intervention is needed directly from the local government.

Empirically, the institutionalization of local government innovation can now be found in some references. In 2009, the United States Agency for International Development (USAID) reported a number of public service management innovation programs carried out by several governments at the local level. The innovation program is a program supported by the Local Government Support Program (LGSP), including: 1) One-Stop-Service in Pinrang Regency (South Sulawesi) and Tebingtinggi Regency (North Sumatra), 2) Citizen Charter in Deli Serdang Regency (North Sumatra) and Boyolali (Central Java), 3) Electronic Citizen Information Service in 
West Aceh Regency (Aceh), 4) Customer Information Management System in Madiun (East Java), and 5) Electronic Government Procurement in the Province West Java.

The five types of innovation programs assisted by the United States Agency for International Development (USAID) in 2009 were considered successful and predicated on good practices, because they fulfilled several things including: 1) the form of the program has been successfully carried out in other countries (having been previously applied in other countries) and widely adapted to local governance in Indonesia (been adapted to the circumstances of local governance in Indonesia), 2) the program has involved multi - stakeholders, procustomers and pro-poor orientation, 3) innovation focus on low cost management solutions to overcome service bottlenecks, and 4) consulting partners with client local government agencies .

In Indonesia Poverty Analysis Program (INDOPOV) in 2006, it was released that the World Bank also conducted research on pro-poor Service Innovation: Nine Case Studies in Indonesia. The nine cases included: 1) Limitation on the Number of Classy Students and Strengthening of Incentives for Education Practitioners in Tanah Datar Regency, West Sumatra, 2) Midwife Service Coupons in Pemalang Regency, Central Java, 3) Development of Learning Communities for Children in Polman Regency, West Sulawesi, 4) Improving Budget Transparency in Bandung City, West Java, 5) Clean Water and Health Programs in Lumajang Regency, East Java, 6) Health Insurance Reform in Jembrana Regency, Bali, 7) Program of Community Block Grant in Blitar City, East Java, 8) Participatory Planning Process in Maros Regency, South Sulawesi, and 9) Civil Service Reform in Boalemo, Gorontalo.

Research conducted by the World Bank (2006) through the Indonesia Poverty Analysis Program (INDOPOV), carried out in the nine cases mentioned above aims to examine innovations in the field of public service at the regency/city level following the implementation of decentralization policies. Although half of the cases were initiated by outsiders namely the World Bank and the other half were initiated by local shareholders, the impact proved to be positive especially for the target group of citizens. An important finding from this World Bank study (2006) is that innovation in the era of implementing decentralization showing that decentralization and local leadership are key factors in providing innovative public service. Most of the innovations learned in the case study will not succeed without the support of national legislation and policies that transfer authority to the local level. The shift of authority, especially in finance and administration, has enabled regional leaders to fund internal reform without donor assistance. Greater regency/city authority also then encourages politicians at the regional level, the general public and donor agencies, to become more interested in the issue of good governance. However, it turns out that the positive impact of these innovations is threatened when the laws and local regulations that support these innovations are still indicated to be weak or unsupportive.

Other problems found by previous researchers, among others, from Orange, et al (2007) which indicated that local government innovation often forgets the existence of social values factors that need attention. These social values include the dimensions of people, the dimensions of the process and the dimensions of technology in the development of innovation. The three social values must be coherent, because if not, innovation will encounter obstacles in its development. The issue of value in the development of innovation was also raised by Pekkarinen, et al (2011), stating that the development of innovation in public sector organizations would be faced with a conflict between old values and new values. This clash of values certainly causes conflict for each adherent. Noting the various issues in developing local government innovations that cover many dimensions, it appears that the development of regional government innovation is still beset by quite complex problems.

Mulgan and Albury (2003) cite several reasons why the public sector must innovate. Some of these reasons include: 1) innovations carried out to respond more effectively to changes in public needs and expectations that continue to increase, 2) to include cost elements and to improve efficiency, 3) to improve the delivery of public services, including sections in the past there has been little progress, 4) to fully capitalize on the use of Information Communication and Technology (ICT), as this has been proven to increase efficiency and effectiveness in service delivery.

From Farazmand's view, it can be understood that innovation is a key factor for sound governance. Innovation factors, both innovation in policy aspects and innovation in administration aspects are central to sound governance. Without innovation, the government will be trapped in damage and ineffectiveness, the government will lose the ability to govern and always be the target of crises and failures. Therefore, sound governance requires continuous innovation in the policies and processes, structures and value systems of government. Policy innovation is the basis to adapt and adjust to rapid environmental changes due to globalization.

Exploring the literature on innovation studies in the development of public administration thinking, it seems that the concept of innovation began to be known before the era of the development of the New Public Management (NPM) paradigm. According to Vigoda-Gadot, et al (2005) that basically the concept of innovation already exists in the era of classic public administration thinking. Although the understanding of innovation in the era of classical administrative thinking, innovation is still understood in a limited sense. Innovation is only meant as an internal mechanism of the organization. Innovation is dominated by top manager so that innovation 
is more top down and only aims to maintain power.

Concept of innovation is originally as a base of excellence in an organization only notable win the competition in the business sector. In its development, this innovation has long been the topic of experts including Korten (1976), Rogers (1983) and Wood, et al (1998) and met its peak when the concept of knowledge management was developed to form an organization's core competence in innovation, Senge (1990) and Muluk (2008). Then the concept of innovation was also developed by scientists and researchers in the field of public administration as an alternative and strategic instrument both politically and administratively in dealing with problems in the increasingly complex public sector. This can be seen from the views of Mulgan \& Albury (2003), Farazmand (2004), Vigoda-Gadot (2005), Borins (2008) and Eggers \& Singh (2009).

In the context of this study, the concept of innovation is understood as an instrument of government administration that has been widely developed and applied in the administration of local government. One of them is the innovation of local government in organizing educational affairs in Kupang City. It is based on the first focus of this research, that is, the process of local government innovation in educational affairs, so the focus of this study conducted in the context of local government having two functions and authority namely the function of regulating and the function of taking care. Hossein \& Muluk (2009). The function of regulating in the context of the administration of educational affairs means that the local government and the Regional House of Representatives (DPRD) carry out the process of forming or formulating policies such as regional regulations which are also referred to as political processes.

While the function of taking care is as a managerial process, namely, the implementation of policies such as regional regulations by local government and regional apparatuses towards policies and programs related to local government innovation in the administration of educational affairs. The process of developing an innovation program can also be understood based on the view of Rogers (1983), that the innovation program is carried out through the process of having needs or problems, research, development, commercialization, diffusion and benefits. And through the opinion of Wood, et al (1998), namely, the process of idea creation, introduction trials, determination of eligibility and application.

The concept of type of innovation in the public sector developed by Mulgan \& Albury (2003) and Muluk (2008), in studies of innovation of public sector are known five types of innovation, namely, a) service product innovation, b) service process innovation, c) service method innovation, d) policy innovation, and e) system innovation. In addition, there is a categorization of the level of innovation which starts from the incremental, radical, and transformative or systemic levels. On the other hand, the concept of the criteria of an innovation program based on the concept of best practices as a basis of innovation developed by Prasojo, et al (2004) which had a positive impact and real, partnership in the process and sustainable guarantee (sustainability). The concept of the type of innovation and the categorization of the level of innovation as well as the innovation program criteria is used as a medium of study analysis to understand more deeply how the types of local government innovations in the administration of educational affairs are developed.

The concept of local government capacity in this context is the ability possessed by local government as public organization in developing local government innovations in the administration of educational affairs. The capacity of local government innovation is intended to achieve the effective and efficient model of local government innovation development. Some capacity concepts presented include the concept of Capacity Building from Grindle (1997) and the Model of Management and Government Innovation developed by Kim, et al (2007). In the context of local government innovation in organizing educational affairs is more relevant using the concept of innovation management capacity model. Innovation by Kim, et al (2007) which includes innovative leadership, the quality of teamwork, systems and structures, as well as the management of external influences.

The experts' views emphasized on the importance of local government innovation. The results of the research of previous researchers which showed a variety of problems in the practice of developing of local government innovation and the existence of facts of innovation in educational affairs. This prompted the writer to conduct an in-depth study on the topic of Innovation of Local Government In Educational Affairs In Kupang City Province East Nusa Tenggara.

\section{Methodology}

The research uses a qualitative approach. Research conducted in Kupang and research sites in all local government institutions and non-government areas that are related to local government innovation programs in implementation of educational affairs. Determination of the location and the site of research conducted purposive, with the reasons, as follows: 1) Kupang City includes one of the autonomous regions which is quite mature and has experience in several stages because government has been established in administrative since 1996; 2) Kupang City is one of the autonomous region which has implemented regional autonomy law in the era of Law Number 22 Year 1999, Law Number 32 Year 2004, and finally Law Number 23 Year 2014 concerning Regional Government; 3) Kupang City has a very strategic geographical and administration location, which is a buffer 
zone for the progress of the Province of East Nusa Tenggara as the center of point for governance and development in the southern area of the Unitary State of the Republic of Indonesia; 4) In Kupang City there are any empirical facts about the development of local government innovation program in educational affairs which are being implemented and can also be applied in other areas.

In the context of the research is primary data obtained from people who have the information and knowledge that is associated with the problem and focus of the research on innovation of governance in organizing the affairs of education in Kupang City. In the context of the research is the data secondary most substantial obtained from documents officially are associated with the activities of government and development through the website of local government of Kupang City. Data secondary which is the macro more lots acquired through the documents were released by the Bureau of Central of Statistics and Agency Planning Regions, such as Kupang City In Figures.

Number and Elements of Research Informant

\begin{tabular}{|c|l|c|l|}
\hline \multicolumn{2}{|c|}{$\begin{array}{l}\text { Informant From the Elements of } \\
\text { Kupang City Regional Administration }\end{array}$} & \multicolumn{2}{|c|}{$\begin{array}{l}\text { Informant From the Elements of } \\
\text { Non Regional Government of Kupang City }\end{array}$} \\
\hline 1 & $\begin{array}{l}\text { Deputy Chairman of the Kupang City DPRD } \\
2\end{array}$ & $\begin{array}{l}\text { One Informant of the Members of the Board of } \\
\text { Education }\end{array}$ \\
\hline 3 & $\begin{array}{l}\text { City DPRD } \\
\text { Kupad of Education \& Culture Office of the }\end{array}$ & 3 & $\begin{array}{l}\text { One Informant from the Chair of the School } \\
\text { Committee }\end{array}$ \\
\hline 4 & $\begin{array}{l}\text { Three Informants from ASN of Education \& } \\
\text { Culture of the Kupang City }\end{array}$ & $\begin{array}{l}\text { One Informant of a Member of the Education } \\
\text { NGO }\end{array}$ \\
\hline 5 & $\begin{array}{l}\text { One Informant of Headmaster and Two } \\
\text { Teachers }\end{array}$ & \\
\hline 6 & \begin{tabular}{l} 
One Education Task Force Member \\
\hline
\end{tabular}
\end{tabular}

Informants of the research on the table are determined through two ways, namely: a) the key person or purposive sampling, namely the appointment of key informants are accidentally as regards those that have understood the information of object that will be investigated, and b) the appointment of informants with snowball sampling, namely determining some people who are considered to be able to provide additional information that reinforces data about the object to be examined.

Data obtained through: 1) interview, 2) observation, 3) documentation, and 4) Focus Group Discussion (FGD). Creswell spiral model data analysis techniques. Through the development of conceptual models of research on regional innovation contributes to the study and understanding of the effectiveness of the development of local government innovation in the administration of education. The conceptual framework of the research can be seen in the following figure:

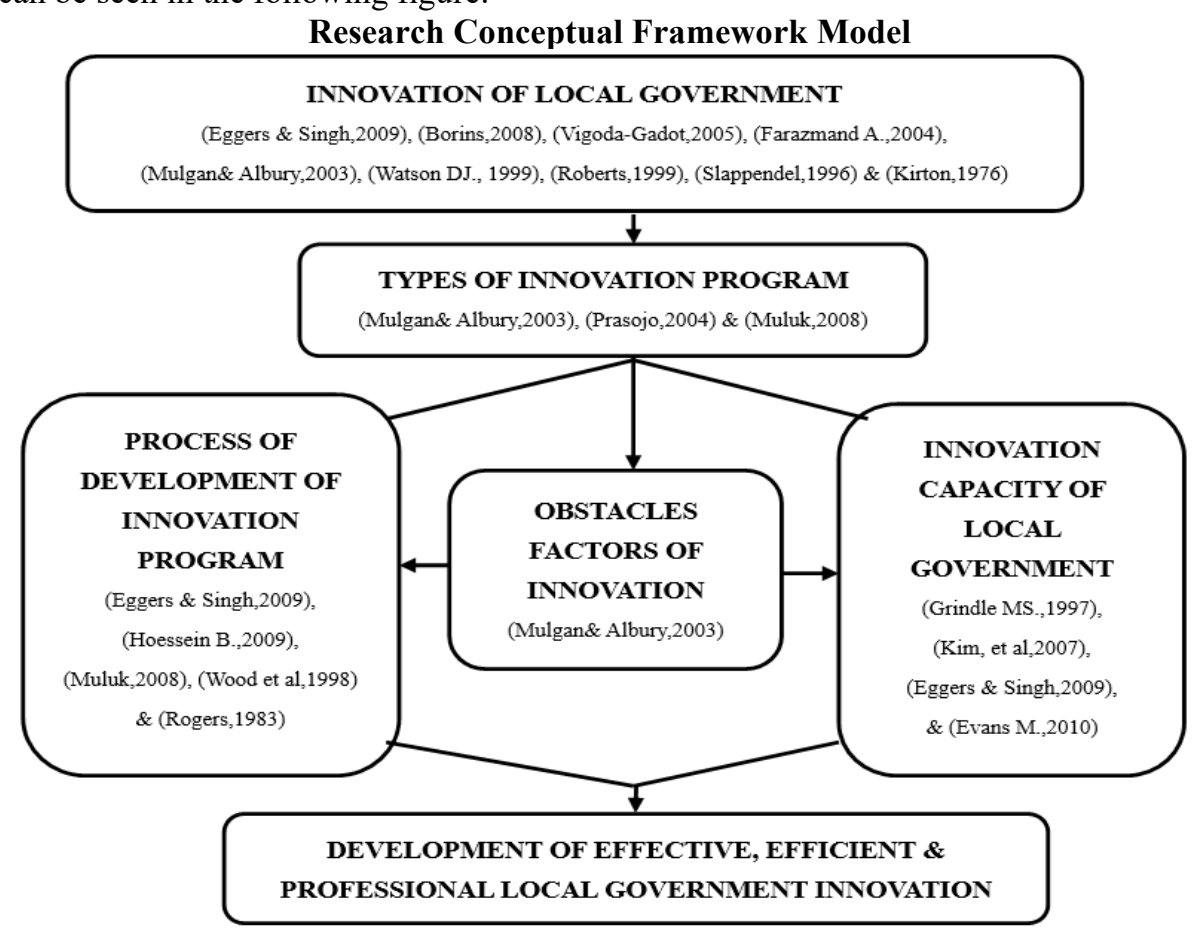




\section{Discussion}

\subsection{The process of development of local government innovation program in education}

The process of development of local government innovation program in the field of education can be studied from the political process, namely, the process of formulation of policy (regulation) and managerial or administration, namely, the process of implementing of policies (management). The political process is the process of formulating policies or regulatory functions carried out by local government institutions and the Regional House of Representatives (DPRD). The policy formulation process regarding this innovation program is a pure initiative of the local government of Kupang City represented by the Office of Education and Culture as the leading sector of educational affairs then discussed together with the Deputy Chairperson of the Regional House of Representatives (DPRD) in this case the Commission on Education. The facts show that the process of formulating policies or forming regional regulations was only followed by the Office of Education and Culture (Executive) and the Education Commission of the Kupang City Regional House of Representatives (DPRD). Meanwhile the Education Board, the Education Expert Team and the local NGO forum were only involved limited to hearing related to the innovation program being formulated. Seeing this fact, it seems that the political process of developing the innovation program has not found anything new or groundbreaking. Whereas, the development of innovation programs should be supported by political processes in the formulation of policies or the formation of regional regulations that are also worth innovation.

Aspects of developing innovation programs related to managerial or administrative processes. This process is the implementation of phase of the policy (Regional Regulation) or the management function carried out by the local government (Mayor of Kupang) assisted by the regional apparatus (local bureaucracy). The facts show that the development process of the entire educational affairs innovation program when viewed from the aspect of the managerial or administrative process is carried out entirely by the bureaucratic structure of the Office of Education and Culture and the relevant Regional Organization (OPD). Then technically the operation of the development process is carried out by the School Unit by involving third parties, namely, the community and consultants partner (private) in certain innovation program. The development of the Children's Education Studio Program (PSPA) and the Education Task Force Program (PSTP) has involved the participation of local communities (Kelurahan) because this program was indeed designed as a local community based program. The Learning Method Innovation Program (PIMP) involves a third party as a consultant partner and the Free Education Program (PPG) is fully carried out by the Office of Education and Culture and the school while the community (parents of students) through the School Committee functions to oversee the realization of the program.

\subsection{This type of innovation program in local government in the field of education}

There are four types of educational affairs innovation programs in Kupang City which are found as well as objects of study, namely: (a) Children Education Studio Program (PSPA), (b) Free Education Program (PPG), (c) Learning Method Innovation Program (PIMP) and (d) Educational Task Force Program (PSTP).

These four programs were not initiated at the same time. The Children Education Studio Program (PSPA) began its development in 2007, the Free Education Program (PPG) was launched in 2008, the development of the Learning Method Innovation Program (PIMP) was first launched in 2010, and the formation of the Educational Task Force Program (PSTP) was carried out in 2010.

The four innovation programs are the results of a comparative study by the local government and adopted with a replication strategy for similar programs in other regions while taking into account the characteristics of the local context needs of the City of Kupang. Types of educational affairs innovation programs have had a real impact on increasing community access to education services (schools) and the quality of learning has also increased and as evidence of the reduced illiteracy rate (ABA) and the Education Index has increased so that the Human Development Index (HDI) of Kupang City is also increasing.

\subsection{The capacity of the City of Kupang Government in developing educational innovation program}

There are five elements of the capacity of the local government of the City of Kupang, which is a sub focus of the development of educational affairs innovation program. The five elements of innovation capacity of the local government are (1) the leadership capacity of the Mayor of Kupang, (2) the capacity of the program implementing apparatus, (3) the capacity of the budget, (4) the capacity of the government innovation network both internal and external government organizations, and (5) the regulatory capacity about the education affairs innovation program.

The Mayor's leadership capacity is very dominant and the success of the innovation program has a high dependency on the capacity of the Regional Budget (APBD) and the National Budget (APBN). Other elements of local government innovation capacity such as implementing apparatuses, government networks and regulations supporting the innovation program are not yet optimal. Although there have been efforts in the form of Education and Training specifically for the development of competencies for apparatus involved in the 
innovation of the Children's Education Studio Program (PSPA), the Learning Method Innovation Program (PIMP) and the Educational Task Force Program (PSTP) originating from the community.

The capacity of the government internal network between the local government and the Regional House of Representatives (DPRD), the local government of the City of Kupang and the government of the Province of East Nusa Tenggara is very strong in supporting the development of educational affairs innovation program.

Empirically, the Mayor of Kupang, since 2006 has begun to initiate an innovation program in educational affairs. The development of this innovation program led Kupang City winning the 2010 and 2011 Otonomi Award from the Fajar Institut Pro Otonomi (FIPO). The fact is in the process of development through political and managerial mechanisms that are not yet optimal. Therefore, this study recommends that the process of developing educational affairs innovation program must be supported by innovative political and managerial/administrative processes. Innovation program can be sourced from internal and external government partners through the adoption process with a replication strategy.

\section{Conclusion}

Based on the results of the analysis can be concluded as follows. First, process of educational affairs innovation program development is done through the political process of policy formulation and process of the managerial/administrative namely the implementation of the policy. Theoretically, the process of formulating and implementing of innovation program policies must also be done innovatively. The process of policy formulation by the local government and the Regional House of Representatives (DPRD) in developing innovation must be carried out democratically, in a participatory and responsive manner and the managerial/administrative process by the local bureaucracy and school units must also take place effectively, efficiently and economically.

Second, the type of innovation program of government sourced from partners both internal and external partners of local government was adopted through a replication strategy of innovation, so that kind of program innovation in local governance do not always contain the value of the new findings (novelty) but the innovation program of local government should have a value of improvement to public service.

Third, program of innovation in the field of education is determined by the dominance of the leadership capacity of the mayor and the availability of budget (APBD/APBN) can be effective for short-term and longterm if it is supported by all available local government capacity comprehensively covering innovative leadership, quality of apparatus (teamwork), strong structures and systems and the ability to manage external influences (politic and network). The development of effective education innovation program at the city level (micro) must be supported by policies and programs in educational affairs at the provincial (meso) and central government (macro) levels.

Recommendations of the research that is the innovation program in field of education must be backed by the political process and the process of managerial/administrative innovative, innovation programs can be sourced from internal and external partners of governance through the adoption process with a replication strategy, policy development and innovation program of local government can take effective short-term and long-term if supported by an innovation capacity that includes innovative leadership, the quality of the apparatus (teamwork), strong structures and systems and the ability to manage external influences (politic and network) and are framed in the design of national innovation policies and programs.

\section{References}

Abdul Wahab, Solichin. (2002). The Future of Regional Autonomy: Social, Economic and Political Studies to Create Synergies in Regional Development. Surabaya: SIC.

Ajibola, MA. (2008). "Innovation and Curriculum Development for Basic Education in Nigeria: Policy Priorities and Challenges of Practice and Implementation". Research Journal of International Studies (Issue 8, November). pp. 51-58.

Akenroye, Temidayo O. \& Christoph W. Kuenne (2015). "Key Competencies for Promoting Service Innovation: What are the Implications for the Health Sector?". The Innovation Journal: The Public Sector Innovation Journal, Volume 20 (1). pp. 1-21.

Akomolafe, Comfort Olufunke. (2011). "Managing Innovations in Educational Systems in Nigeria: A Focus on Creating and Sustenance of Culture of Innovation". Journal of Emerging Trends in Educational Research and Policy Studies (JETERAPS) 2 (1). pp. 47-52.

Creswell, John W. (2007). Qualitative Inquiry \& Research Design; Choosing Among Five Approaches. London: Sage Publications.

Farazmand, Ali (Ed.). (2004). Sound Governance: Policy and Administrative Innovations . London: Praeger.

Farazmand, Ali. (2004) "Innovation in Strategic Human Resource Management: Building Capacity in the Age of Globalization". Public Organization Review: A Global Journal 4: 3-24.

Grindle, Merilee S. (Editor). (1997). Getting Good Government: Capacity Building in the Public Sector of 
Developing Countries. Boston, MA: Harvard Institute for International Development.

Hoessein, Bhenyamin. (2009). Changes, Models, Patterns and Forms of Regional Government: From the New Order Era to the Reformation Era. Department of Administrative Sciences: FISIP-UI.

INDOPOV. (2007). Pro-Poor Service Innovation: Nine Case Studies in Indonesia. The World Bank: Poverty Reduction and Economic Management Unit of the East Asia and Pacific Region.

Kim, Seok Eun, Jung Wook Lee \& Byong Seob Kim. (2007). The Quality of Management and Government Innovation: An Empirical Study. A paper for presentation at the 9th Public Management Research

Conference, University of Arizona, October 25-27.

Mulgan, G. \& Albury, D. (2003). Innovation in the Public Sector. Working paper version 1.9, October, Strategy Unit UK Office Cabinet.

Muluk ,Khairul. (2008). Knowledge Management; The Key to Successful Regional Government Innovation . Malang: Bayu Media.

Orange, Graham. et al., (2007). "Local Government and Social or Innovation Values". Transforming Government: People, Process and Policy. Volume 1 No. 3, pp. 242-254.

Pekkarinen, Satu.,Tomi Tura., Lea Hennala \& Vesa Harmaakorpi. (2011). "Clashes as Potential for Innovation in Public Service Sector Reform": International Journal of Public Sector Management: Vol. 24 No. 6, pp. 507-532.

Prasojo, Eko. (2006). "Bureaucratic Reform in Indonesia: Some Critical Notes", Journal of Business \& Bureaucracy, Vol. XIV/No.1 / January. Department of Administrative Sciences FISIP UI.

Rogers, Everett M. (1983). Diffusion of Innovations. Third Edition. New York: Macmillan Publishing Co., Inc.

Smith, Brian C. (1985). Decentralization: The Territorial Dimension of the State. London: George Allen \& Unwin.

Solihin, Dadang. (2010). Decentralization and Regional Autonomy. Darma Persada University. Via: www.dadangsolihin.com/lecture.

Suwandi, Made. (2007). Principal Thoughts; Basic Conceptions of Indonesian Regional Autonomy (In Efforts to Create Democratic and Efficient Local Government). Jakarta: Directorate General of Regional Autonomy of the Ministry of Home Affairs.

USAID. (2009). Innovations in Local Service Management: Challenges and Opportunities in Decentralized Governance in Indonesia. Good Governance Brief. LGSP-USAID.

Vigoda-Gadot, Eran, Aviv Shoham, Nitza Schwabsky, \& Ayalla Ruvi. (2005). "Public Sector Innovation for the Managerial and Post-Managerial Era: Promises and Realities in a Globalizing Public Administration". International Public Management Journal.8 (1) p. 57-81.

Wood, JM, Wallace, J., Zeffane, RM, Schermerhom, JR, Hunt, JG, \& Osborn, RN. (1998). Organizational Behavior: An Asia-Pacific Perspective. Brisbane: John Wiley \& Sons. 